medRxiv preprint doi: https://doi.org/10.1101/2020.05.28.20115501; this version posted June 1, 2020. The copyright holder for this preprint

(which was not certified by peer review) is the author/funder, who has granted medRxiv a license to display the preprint in perpetuity.

It is made available under a CC-BY-NC 4.0 International license .

\title{
Development and external validation of a diagnostic model for in-hospital bleeding \\ in patients with acute ST elevation myocardial infarction
}

\section{Yong $\mathrm{Li}$}

Emergency and Critical Care Center, Beijing Anzhen Hospital, Capital Medical University, Beijing 100029, China;

E-mail:liyongdoctor@sina.com

Correspondence Author: Yong Li, Emergency and Critical Care Center, Beijing Anzhen Hospital, Capital Medical University, Beijing 100029, China; Telephone Numbers: +86 13910227262, Fax Numbers: 008601068000030 , ORCID: 0000-0002-2999-8164.

Keywords: coronary disease; ST elevation myocardial infarction; hemorrhage; nomogram

\begin{abstract}
Background: Bleeding complications in patients with acute ST segment elevation myocardial infarction (STEMI) are associated with an increased risk of subsequent adverse consequences. We want to develop and externally validate a diagnostic model of in-hospital bleeding in the population of unselected real-world patients with acute STEMI.

Methods: Design: Multivariable logistic regression of a cohort for hospitalized patients with acute STEMI . Setting: Emergency department ward of a university hospital. Participants: Diagnostic model development: Totally 4262 hospitalized patients with acute STEMI from January 2002 to December 2013 in Beijing Anzhen Hospital, Capital Medical University. External validation: Totally 6015 hospitalized patients with acute STEMI from January 2014 to August 2019 in Beijing Anzhen Hospital, Capital Medical University. Outcomes: All-cause in-hospital bleeding not related to coronary artery bypass graft surgery or catheterization.
\end{abstract}

Results: In-hospital bleeding occurred in 2.6\% ( $112 / 4262$ ) of patients in the development data set and $1.9 \%(117 / 6015)$ of patients in the validation data set. The strongest predictors of in-hospital bleeding were advanced age and high Killip classification. We developed a diagnostic model of in-hospital bleeding. The area under the receiver operating characteristic ( ROC ) curve (AUC) was 
medRxiv preprint doi: https://doi.org/10.1101/2020.05.28.20115501; this version posted June 1, 2020. The copyright holder for this preprint

(which was not certified by peer review) is the author/funder, who has granted medRxiv a license to display the preprint in perpetuity.

It is made available under a CC-BY-NC 4.0 International license.

$0.777 \pm 0.021,95 \%$ confidence interval $(\mathrm{CI})=0.73576 \sim 0.81823$. We constructed a nomograms using the development database based on age, and Killip classification. The AUC was $0.7234 \pm 0.0252$, $95 \% \mathrm{CI}=0.67392 \sim 0.77289$ in the validation data set. Discrimination, calibration, and decision curve analysis were satisfactory.

Conclusions: We developed and externally validated a moderate diagnostic model of in-hospital bleeding in patients with acute STEMI .

We registered this study with WHO International Clinical Trials Registry Platform (ICTRP) (registration number: ChiCTR1900027578; registered date: 19 Novmober 2019). http://www.chictr.org.cn/edit.aspx ?pid=45926\&htm=4.

Key Words: coronary disease; ST elevation myocardial infarction; hemorrhage; nomogram

\section{Background}

Hemorrhagic complications occurred in nearly $8.5 \%$ of patients with acute ST segment elevation myocardial infarction (STEMI) during hospitalization. ${ }^{[1,2]}$ Bleeding events are associated with an increased risk of adverse outcomes in patients with STEMI. ${ }^{[3-6]}$ Prevention of bleeding may represent an achievable step. We want to develop and externally validate a diagnostic model of in-hospital bleeding in the population of unselected real-world patients with acute STEMI. The aim of our study was 4-fold: (1) to identify predictive factors; (2) to develop a diagnostic model; (3) to create a nomogram and (4) to externally validate diagnostic model.

\section{Methods}

We used a Type $2 \mathrm{~b}$ predictive model study, which covered by Transparent Reporting of a multivariable prediction model for Individual Prognosis Or Diagnosis (TRIPOD) statement. ${ }^{[7]}$ The data was divided into two groups non-randomly according to time: one group was used to develop a prediction model, and the other group was used to evaluate its prediction performance. ${ }^{[7]}$ Type $2 \mathrm{~b}$ was called"external verification study". ${ }^{[7]}$

The derivation cohort was 4262 hospitalized patients with acute STEMI from January 2002 to 
medRxiv preprint doi: https://doi.org/10.1101/2020.05.28.20115501; this version posted June 1, 2020. The copyright holder for this preprint

(which was not certified by peer review) is the author/funder, who has granted medRxiv a license to display the preprint in perpetuity.

It is made available under a CC-BY-NC 4.0 International license .

December 2013 in Beijing Anzhen Hospital, Capital Medical University.

The validation cohort was 6015 hospitalized patients with acute STEMI from January 2014 to

August 2019 in Beijing Anzhen Hospital, Capital Medical University.

Inclusion criteria: 1 . hospitalized patients with acute STEMI; 2. age of more than 18 years.

We established the diagnosis of acute myocardial infarction (AMI) and STEMI base on the fourth universal definition of myocardial infarction. ${ }^{[8]}$

Exclusion criteria: none.

It was a retrospective analysis and informed consent was waived by Ethics Committee of Beijing Anzhen Hospital Capital Medical University.

Outcome of interest was all-cause in-hospital bleeding not related to coronary artery bypass graft surgery or catheterization during hospitalization, as defined according to the Bleeding Academic Research Consortium criteria2, 3, and 5. ${ }^{[4]}$ The presence or absence of in-hospital bleeding was decided blinded to the predictor variables and based on the medical record.

We selected 13 predictor according to clinical relevance and the results of baseline descriptive statistics. The potential candidate variables were age ,sex, Killip classification, atrioventricular block (AVB), atrial fibrillation(AF), underwent percutaneous coronary intervention(PCI)during hospitalization, and medical history such as hypertension, diabetes, myocardial infarction, PCI, coronary artery bypass grafting (CABG), cerebrovascular disease (HCD), and chronic

kidney disease(CKD). All of them based on the medical record. AF defined as all type of AF during hospitalization. AVB defined as all type of AVB during hospitalization.

Some people suggest that each candidate variable has at least 10 events for model derivation and at least 100 events for validation studies. ${ }^{[7]}$ Our number of samples and events exceeds all approaches used to determine sample size, so it is expected to provide a very reliable estimate. In order to ensure the reliability of the data, we excluded patients who lacked information on key predictors: age and Kilip classification. The reason for excluding all patients was the lack of Killip classification. 
medRxiv preprint doi: https://doi.org/10.1101/2020.05.28.20115501; this version posted June 1, 2020. The copyright holder for this preprint

(which was not certified by peer review) is the author/funder, who has granted medRxiv a license to display the preprint in perpetuity.

It is made available under a CC-BY-NC 4.0 International license .

\section{Statistical analysis.}

We kept all continuous data as continuous and retained on the original scale. Based on the variables significantly generated by univariate logistic regression, we constructed a multivariate logistic regression model using the backward variable selection method.We used the Akanke information criterion (AIC) and Bayesian information criterion(BIC)to select predictors. It considers model fitting and penalizes the estimated number of parameters, which is equivalent to using $\alpha=0.157$. $^{[7]}$ We assessed the predictive performance of the diagnostic model in the validation data sets by examining measures of discrimination, calibration, and decision curve analysis (DCA). ${ }^{[7,9]}$ Discrimination is the ability of the diagnostic model to differentiate between patients who with and without in-hospital bleeding. This measure was quantified by calculating the area under the receiver operating characteristic (ROC) curve (AUC). ${ }^{[7]}$ Calibration refers to how closely the predicted in-hospital bleeding agrees with the observed in-hospital bleeding. ${ }^{[7]}$ The Brier score was an aggregate measure of disagreement between the observed outcome and a prediction — the average squared error difference. We used DCA to describe and compare the clinical effects of diagnostic model. ${ }^{[7]}$ We performed statistical analyses with STATA version 15.1 (StataCorp, College Station, TX), R version 4.0.0( R Development Core Team; http://www.r-project.org ) and the RMS package developed by Harrell ( Harrell et al ). All tests were two-sided and a P value $<0.05$ was considered statistically significant.

\section{Results}

We drew a flow diagrams (Figure 1). 


\section{Flow Diagams}
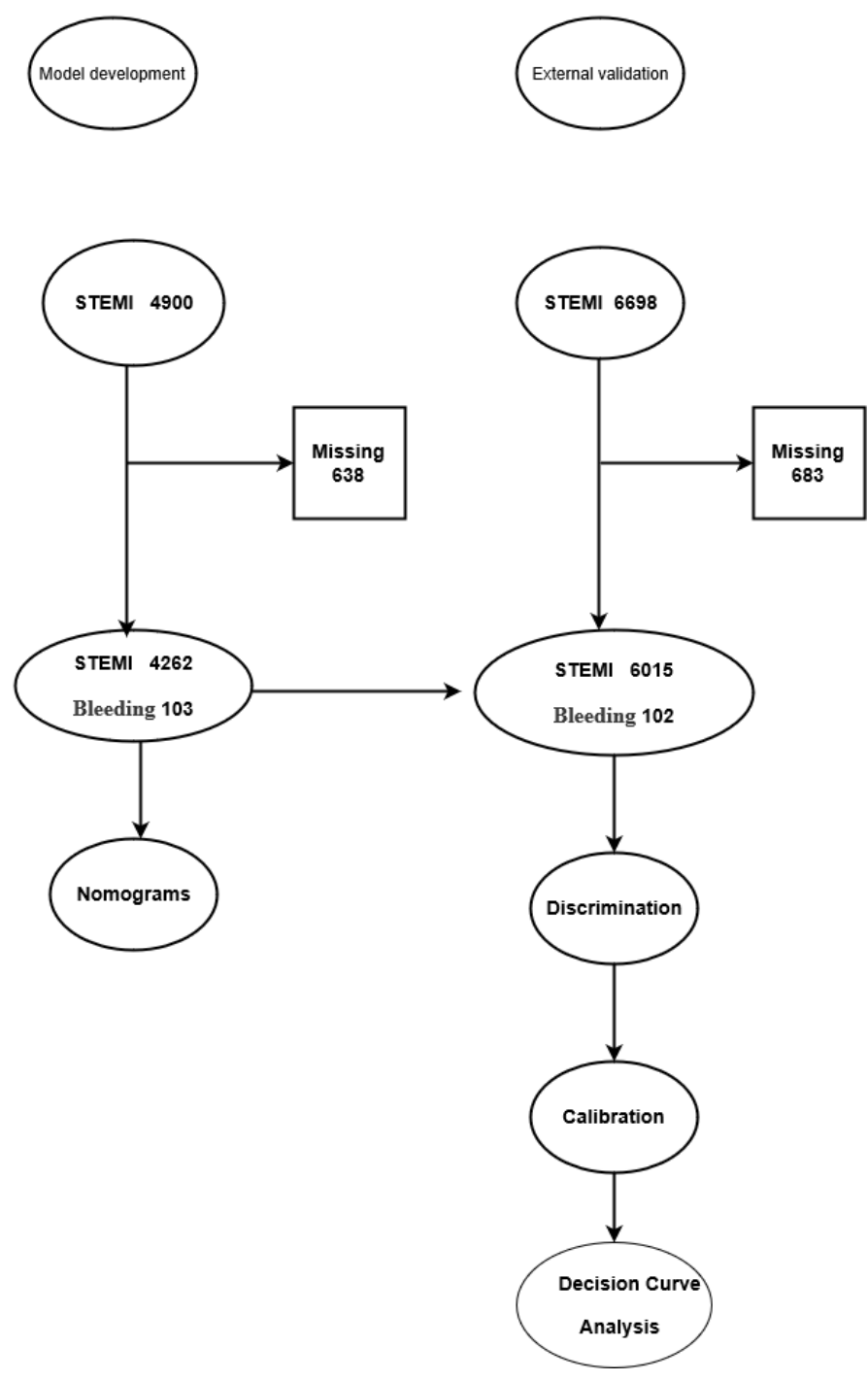

Figure 1. Flow diagrams

In the development data set, a total of 2.6\% (112/4262) of hospitalized patients experienced in-hospital bleeding. The patient's baseline characteristics were shown in Table 1.Nine variables (age , sex , Killip classification, AVB , AF , history of CABG, history of diabetes, history of CKD , and underwent PCI during hospitalization)were significant differences in the two groups of patients $(\mathrm{p}<0.157)$. After application of backward variable selection method, AIC, and BIC, age remained as a significant independent predictors of in-hospital bleeding;Killip classification remained as a rank variable of in-hospital bleeding. Results were shown in Table 2 and Table3.

Table 1. Demographic and clinical characteristics of patients with and without in-hospital bleeding 
medRxiv preprint doi: https://doi.org/10.1101/2020.05.28.20115501; this version posted June 1, 2020. The copyright holder for this preprint (which was not certified by peer review) is the author/funder, who has granted medRxiv a license to display the preprint in perpetuity.

It is made available under a CC-BY-NC 4.0 International license.

in the development data sets

\begin{tabular}{|c|c|c|c|c|}
\hline $\begin{array}{l}\text { Characteristic } \\
\text { [lower limit, upper limit] }\end{array}$ & $\begin{array}{l}\text { Total } \\
(\mathrm{n}=4262)\end{array}$ & $\begin{array}{l}\text { In -hospital bleeding } \\
(\mathrm{n}=112)\end{array}$ & $\begin{array}{l}\text { No bleeding } \\
(\mathrm{n}=4150)\end{array}$ & P value \\
\hline Age (year, $x \pm s)[21,99]$ & $60 \pm 13$ & $70 \pm 10$ & $60 \pm 13$ & $<0.001$ \\
\hline Man n (\%) $0=$ No, $1=$ Yes & $3248(76.2)$ & $73(65.2)$ & $3175(76.5)$ & 0.006 \\
\hline \multicolumn{5}{|l|}{ Medical history } \\
\hline \multicolumn{5}{|l|}{$\mathrm{n}(\%) 0=\mathrm{No}, 1=\mathrm{Yes}$} \\
\hline Hypertension & $2372(55.7)$ & $63(56.3)$ & $2309(55.6)$ & 0.898 \\
\hline Diabetes & $1246(29.2)$ & $42(37.5)$ & 1204(29) & 0.053 \\
\hline Myocardial infarction & $426(10)$ & 13(11.6) & $413(10)$ & 0.565 \\
\hline PCI & $228(5.3)$ & $7(6.3)$ & $221(5.3)$ & 0.668 \\
\hline CABG & $28(0.7)$ & $2(1.8)$ & $26(0.6)$ & 0.152 \\
\hline CKD & $95(2.2)$ & $7(6.3)$ & $88(2.1)$ & 0.006 \\
\hline HCD & $338(7.9)$ & $11(9.8)$ & $327(7.9)$ & 0.454 \\
\hline \multicolumn{5}{|l|}{ Killip classification } \\
\hline $\mathrm{n}(\%) \quad 0=$ No, $1=$ Yes & & & & \\
\hline Killip I & $769(18)$ & 13(11.6) & $756(18.2)$ & 0.076 \\
\hline Killip II & $2565(60.2)$ & $31(27.7)$ & $2534(61.1)$ & $<0.001$ \\
\hline Killip III & $533(12.5)$ & $32(28.6)$ & $501(12.1)$ & $<0.001$ \\
\hline Killip IV & $395(9.3)$ & $36(32.1)$ & $359(8.7)$ & $<0.001$ \\
\hline $\mathrm{AF} n(\%) 0=\mathrm{No}, 1=\mathrm{Yes}$ & $243(5.7)$ & $15(13.4)$ & $228(5.5)$ & 0.001 \\
\hline AVB n $(\%) 0=$ No, $1=$ Yes & 197(4.6) & 13(11.6) & $184(4.4)$ & 0.001 \\
\hline Underwent PCI n (\%) $0=\mathrm{No}, 1=$ Yes & $3103(72.8)$ & $50(44.6)$ & 3053(73.6) & $<0.001$ \\
\hline
\end{tabular}

$\mathrm{AF}=$ atrial fibrillation $; \mathrm{AVB}=$ atrioventricular block $; \mathrm{CABG}=$ coronary artery bypass grafting $; \mathrm{CKD}=$ chronic

kidney disease ; $\mathrm{HCD}=$ cerebrovascular disease ; Underwent $\mathrm{PCI}=$ underwent PCI during hospitalization.

Table 2. Predictor of in-hospital bleeding obtained from multivariable logistic regression models ( odds ratio )

in the development data set

\begin{tabular}{lllll}
\hline In -hospital bleeding & Odds ratio & Std.Err & $\mathrm{Z}$ & $\mathrm{P}>|\mathrm{Z}|$
\end{tabular}


medRxiv preprint doi: https://doi.org/10.1101/2020.05.28.20115501; this version posted June 1, 2020. The copyright holder for this preprint (which was not certified by peer review) is the author/funder, who has granted medRxiv a license to display the preprint in perpetuity.

It is made available under a CC-BY-NC 4.0 International license .

\begin{tabular}{llllll}
\hline Age & 1.047443 & .0095986 & 5.06 & $<0.001$ & $1.028798 \sim 1.066426$ \\
Killip III & 3.265072 & .8100203 & 4.77 & $<0.001$ & $2.007804 \sim 5.309632$ \\
Killip IV & 5.132613 & 1.240357 & 6.77 & $<0.001$ & $3.196212 \sim 8.242169$ \\
_cons & .0007621 & .0004685 & -11.68 & $<0.001$ & $.0002285 \sim .0025424$ \\
\hline CI =confidence interval. & & & &
\end{tabular}

$\mathrm{CI}=$ confidence interval

Table 3. Predictor of in-hospital bleeding obtained from multivariable logistic regression models ( Coef )

in the development data sets

\begin{tabular}{lccccc}
\hline In -hospital bleeding & Coef & Std.Err & Z & P $>|Z|$ & $95 \%$ CI \\
\hline Age & .0463523 & .0091638 & 5.06 & $<0.001$ & $.0283915 \sim .0643131$ \\
Killip III & 1.183282 & .2480865 & 4.77 & $<0.001$ & $.6970414 \sim 1.669523$ \\
Killip IV & 1.635615 & .2416619 & 6.77 & $<0.001$ & $1.161966 \sim 2.109263$ \\
_cons & -7.179377 & .6146614 & -11.68 & $<0.001$ & $-8.384092 \sim-5.974663$ \\
\hline & & & & &
\end{tabular}

According to the above risk factors, we can calculate the predicted probability of in-hospital

bleeding using the following formula: $\mathrm{P}=1 /(1+\exp (-(-7.179377+.0463523 * \mathrm{AGE}(\mathrm{year})$

$+1.183282 * \mathrm{KIII}+1.635615 * \mathrm{KIV}))) . \mathrm{KIII}=$ Killip III $(0=$ No, $1=$ Yes $), \mathrm{KIV}=\mathrm{Killip}$ IV $\quad(0=$ No,

$1=$ Yes ) .The ROC curve was drawn (Figure 2).AUC was $0.777 \pm 0.021,95 \%$ confidence

interval $(\mathrm{CI})=0.73576 \sim 0.81823$. 


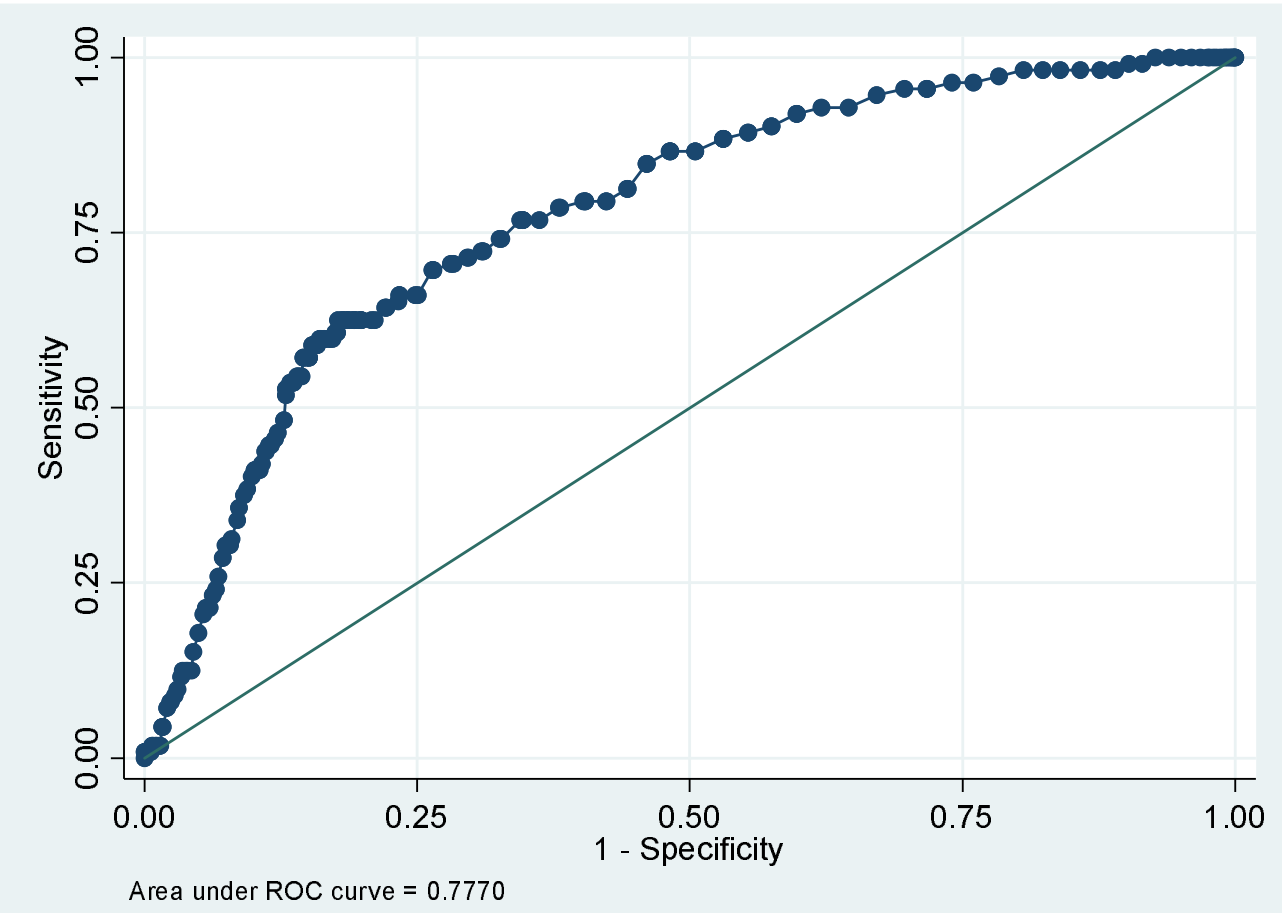

Figure 2. Receiver-operating characteristics curve in identifying patients with in-hospital bleeding in the development dataset.

We constructed the nomogram (Figure 3) using the development database based on a independent prognostic marker and a rank variable: age and Killip classification.

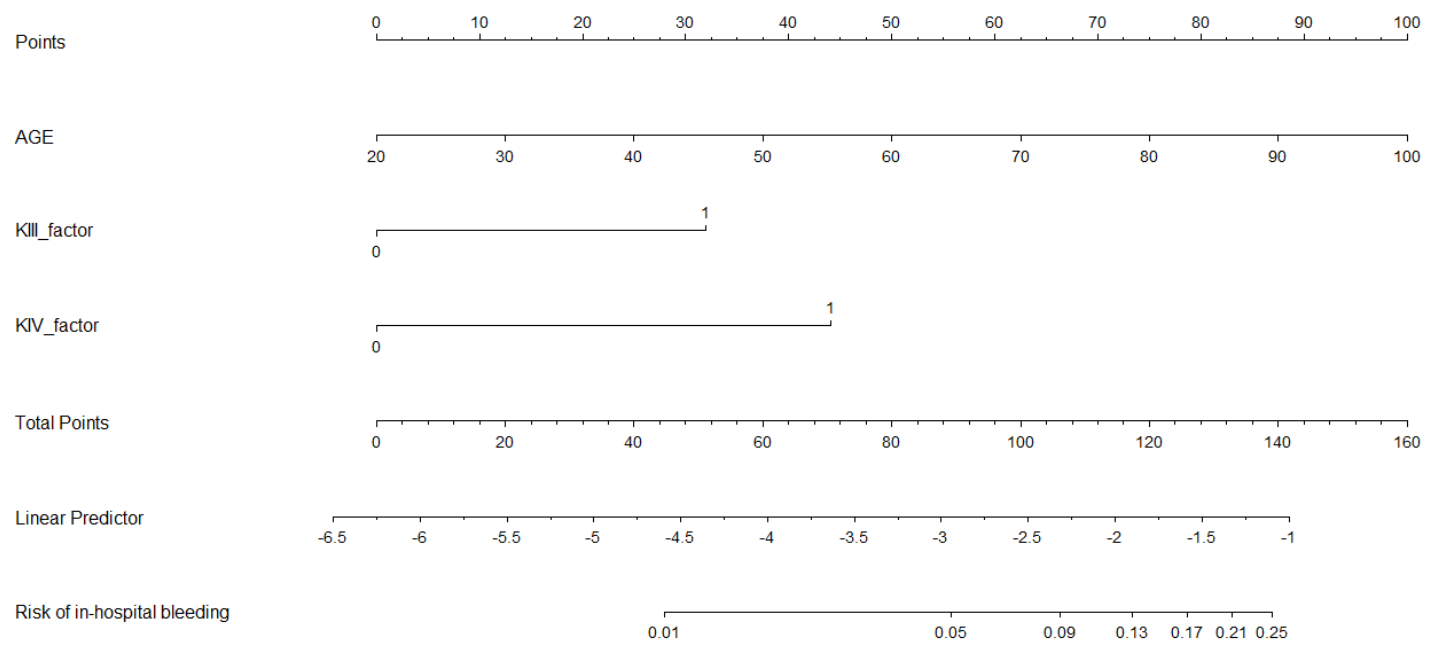

Figure 3. A nomograms for predicting in-hospital bleeding in patients with acute STEMI AGE= Age(year); KIII-factor= Killip III ; KIV-factor = Killip IV. 
Totally $1.9 \%$ ( $117 / 6015)$ hospitalized patients suffered in-hospital bleeding in the validation data sets. Baseline characteristics of the patients were shown in Table 4. We can calculate the predicted probability of in-hospital bleeding using the following formula: $\mathrm{P}=1 /(1+\exp (-(-7.179377$ $+.0463523 * \mathrm{AGE}($ year $)+1.183282 * \mathrm{KIII}+1.635615 * \mathrm{KIV}))) . \mathrm{KIII}=\mathrm{Killip}$ III ( $0=$ No, 1=Yes ) , KIV= Killip IV （ $0=$ No, $1=$ Yes $)$. We drew the ROC curve ( Figure 4 ).AUC was $0.7234 \pm 0.0252$,

$95 \% \mathrm{CI}=0.67392 \sim 0.77289$.

Table 4. Demographic and clinical characteristics of patients with and without in-hospital bleeding in the validation data sets

\begin{tabular}{|c|c|c|c|c|}
\hline $\begin{array}{c}\text { Characteristic } \\
\text { [lower limit, upper limit] }\end{array}$ & $\begin{array}{l}\text { Total } \\
(\mathrm{n}=6015)\end{array}$ & $\begin{array}{l}\text { In-hospital bleeding } \\
(\mathrm{n}=117)\end{array}$ & $\begin{array}{l}\text { No bleeding } \\
(n=5898)\end{array}$ & $P$ value \\
\hline Age (year, $x \pm s)[21,92]$ & $59 \pm 12$ & $64 \pm 12$ & $58 \pm 12$ & $<0.001$ \\
\hline Man n $(\%) 0=$ No, $1=$ Yes & 4894(81.4) & $86(73.5)$ & $4808(81.5)$ & 0.029 \\
\hline \multicolumn{5}{|l|}{ Medical history, n (\%) } \\
\hline \multicolumn{5}{|l|}{$0=$ No, $1=$ Yes } \\
\hline Hypertension & $3427(57)$ & $65(55.6)$ & $3362(57)$ & 0.754 \\
\hline Diabetes & $1822(30.3)$ & $40(34.2)$ & $1782(30.2)$ & 0.355 \\
\hline Myocardial infarction & $433(7.2)$ & $14(12)$ & $419(7.1)$ & 0.047 \\
\hline PCI & $575(9.6)$ & $18(15.4)$ & $557(9.4)$ & 0.033 \\
\hline $\mathrm{CABG}$ & $51(0.8)$ & $3(2.6)$ & $48(0.8)$ & 0.053 \\
\hline CKD & $145(2.4)$ & $4(3.4)$ & $141(2.4)$ & 0.475 \\
\hline $\mathrm{HCD}$ & $421(7)$ & $12(10.3)$ & $409(6.9)$ & 0.166 \\
\hline \multicolumn{5}{|l|}{ Killip classification } \\
\hline $\mathrm{n}(\%) \quad 0=\mathrm{No}, 1=\mathrm{Yes}$ & & & & \\
\hline Killip I & $4234(70.4)$ & $45(38.5)$ & $4189(71)$ & $<0.001$ \\
\hline Killip II & $1188(19.7)$ & $31(26.5)$ & 1157(19.6) & 0.066 \\
\hline Killip III & $266(4.4)$ & $11(9.4)$ & $255(4.3)$ & 0.010 \\
\hline Killip IV & $330(5.5)$ & $30(25.6)$ & $300(5.1)$ & $<0.001$ \\
\hline
\end{tabular}


medRxiv preprint doi: https://doi.org/10.1101/2020.05.28.20115501; this version posted June 1, 2020. The copyright holder for this preprint (which was not certified by peer review) is the author/funder, who has granted medRxiv a license to display the preprint in perpetuity. It is made available under a CC-BY-NC 4.0 International license .

$\begin{array}{lllll}\text { AF n }(\%) 0=\text { No, } 1=\text { Yes } & 275(4.6) & 12(10.3) & 263(4.5) & 0.004 \\ \text { AVB n }(\%) 0=\text { No, } 1=\text { Yes } & 119(2) & 3(2.6) & 116(2) & 0.647 \\ \text { Underwent PCI n }(\%) 0=\text { No, } 1=\text { Yes } & 4564(75.9) & 70(59.8) & 4494(76.2) & <0.001\end{array}$

Abbreviations as in Table 1.

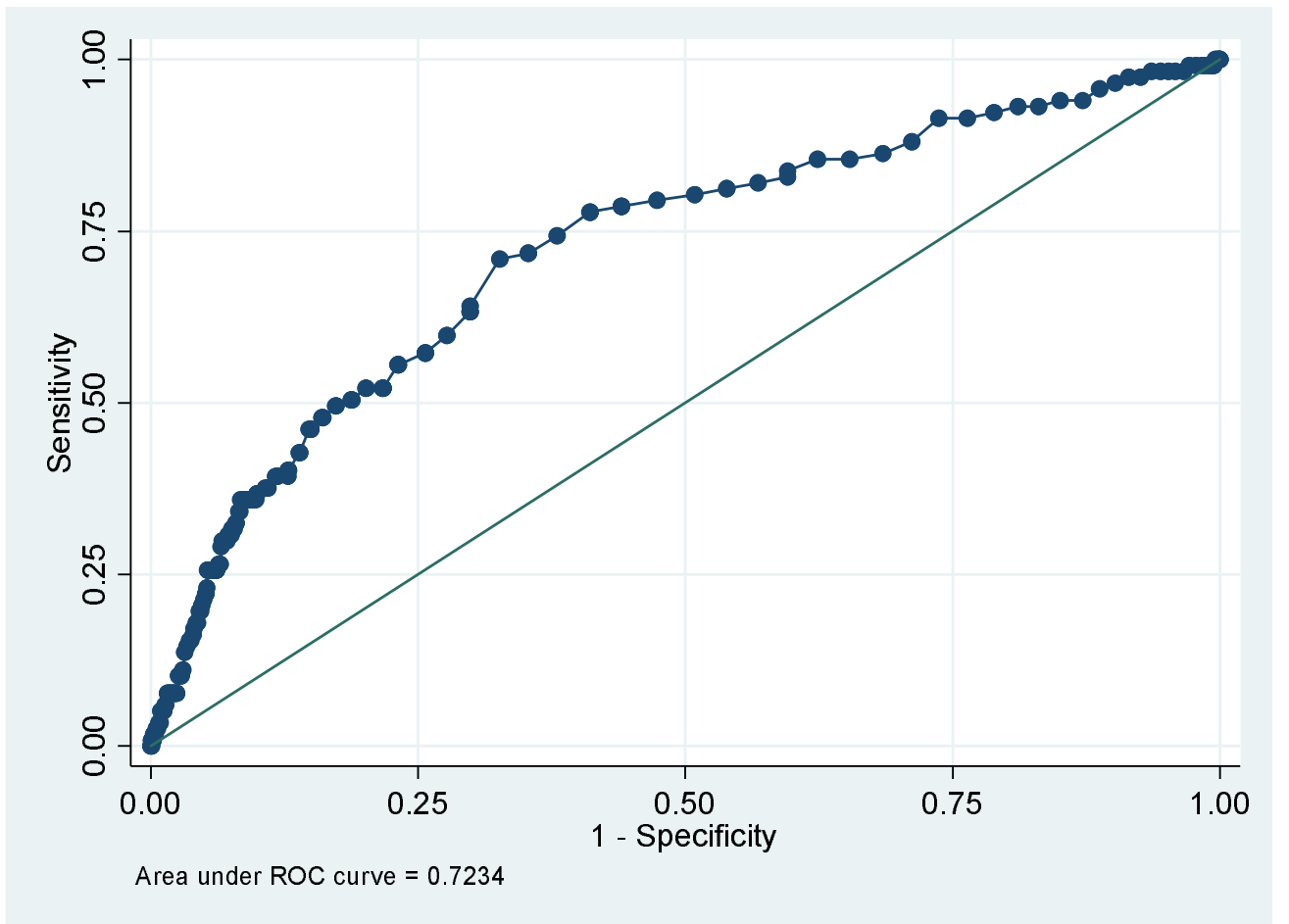

Figure 4. Receiver-operating characteristics curve in identifying patients with in-hospital bleeding in the validation data sets

We drew a calibration plot (Figure 5) with distribution of the predicted probabilities for individuals with and without in-hospital bleeding in the validation data sets.Hosmer-Lemeshow chi2 $(10)=$ 10.64, Prob $>$ chi2 $=0.3859>0.05$. Brier score $=0.0188<0.25$. 


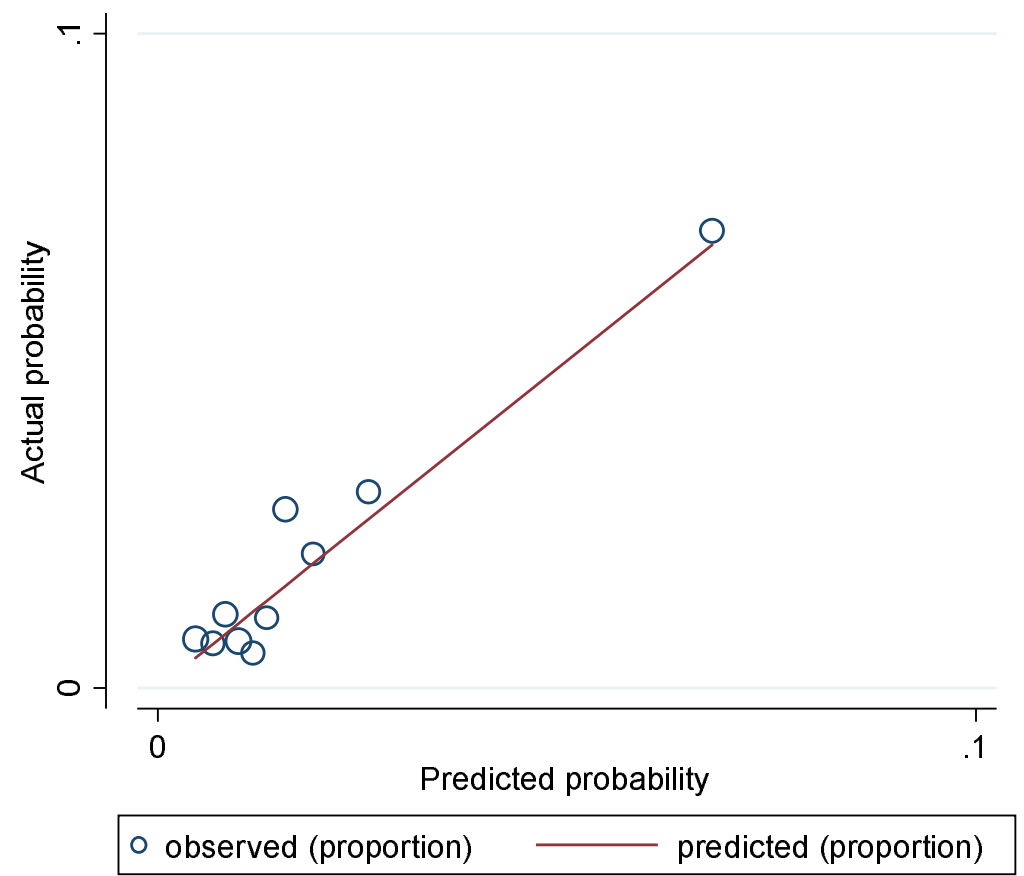

Figure 5. A calibration plot with distribution of the predicted probabilities for individuals with and without in-hospital bleeding in the validation data sets.

DCA(Figure 6) in the validation data sets.

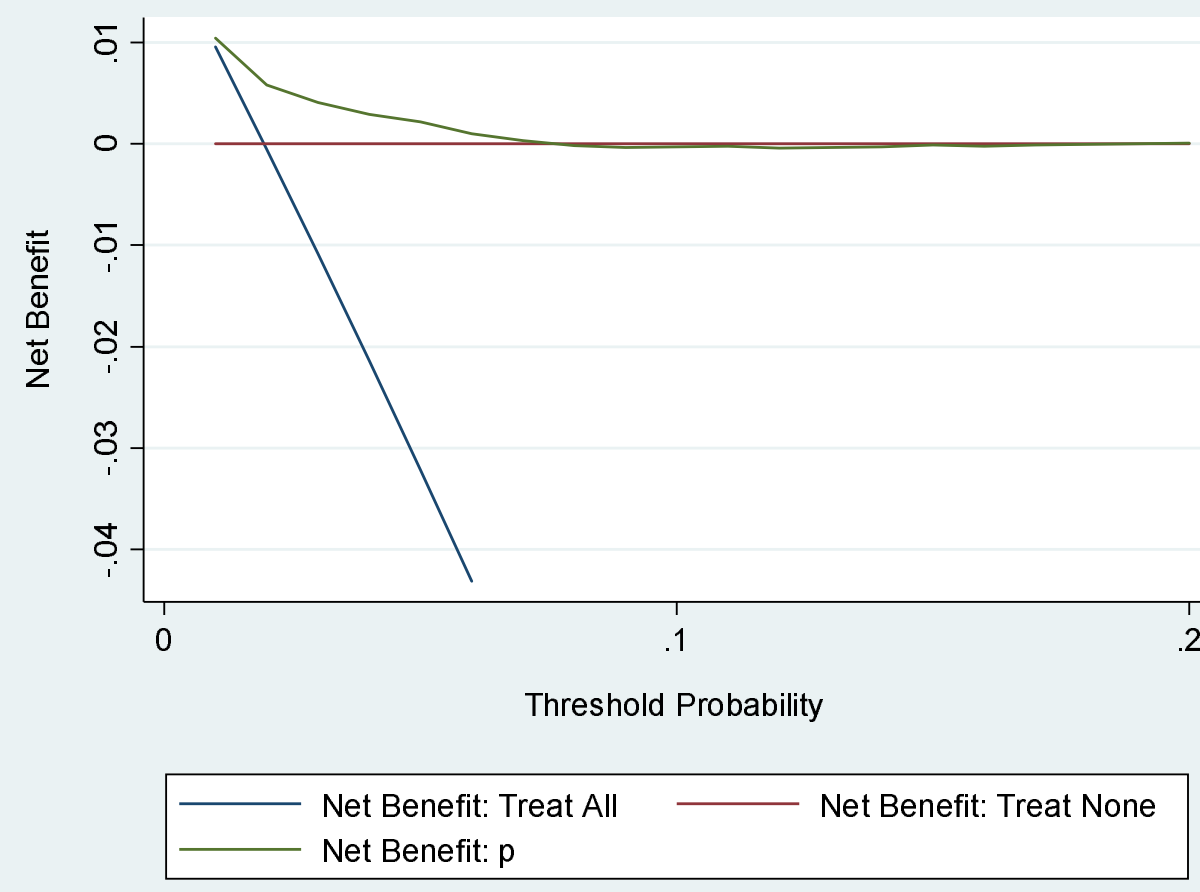

Figure 6. DCA in the validation data sets. 
medRxiv preprint doi: https://doi.org/10.1101/2020.05.28.20115501; this version posted June 1, 2020. The copyright holder for this preprint

(which was not certified by peer review) is the author/funder, who has granted medRxiv a license to display the preprint in perpetuity.

It is made available under a CC-BY-NC 4.0 International license .

\section{Discussion}

We assessed the predictive performance of the diagnostic model in the validation data sets by examining measures of discrimination, calibration , and DCA. AUC was $0.7234 \pm 0.0252,95 \% \mathrm{CI}=$ $0.67392 \sim 0.77289$ in the validation data sets. Hosmer-Lemeshow chi2 $(10)=10.64$, Prob $>$ chi $2=0$. $3859>0.05$. Brier score $<0.25$. Discrimination, calibration, and DCA were satisfactory. In our study, advanced age and high Killip classification are associated with an increased risk of in-hospital bleeding in patients with acute STEMI. We can use the formula or nomogram to predicte in-hospital bleeding. We can use specific strategies to reduce the risk of in-hospital bleeding, such as paying attention to the appropriate dose of antithrombotic drugs.

The high Killip classification is associated with an increased risk of bleeding. ${ }^{[3,10,11]}$ In our study, patients with Killip class IV were at 5.1 higher risk of in-hospital bleeding than patients with Killip class I III. Insufficient tissue perfusion adversely affects the coagulation system and platelet function. ${ }^{[11]}$ Insufficient tissue perfusion may cause gastritis or ulceration and increase the possibility of gastrointestinal bleeding. ${ }^{[11]}$

Advanced age has been reported to be an independent risk factor of bleeding. ${ }^{[3,11-15]}$ Age may change the balance between the risks and benefits of treatment strategies. ${ }^{[16]}$ The cause of the higher risk of bleeding in the elderly may be multifactorial, including decreased kidney function and increased sensitivity to anticoagulants. ${ }^{[17]}$ It is speculated that the presence of local vascular changes is a potential explanation for the increased incidence of bleeding complications in elderly patients. ${ }^{[6]}$ It is recommended that elderly patients have stomach protection. ${ }^{[18]}$

Moscucci et al. observed that seniors, women, history of bleeding and renal insufficiency were independent predictors of major bleeding among the patients with 8151 STEMI, 7440 non-ST elevation myocardial infarction (NSTEMI) and 8454 unstable angina registered in the Global Acute 
medRxiv preprint doi: https://doi.org/10.1101/2020.05.28.20115501; this version posted June 1, 2020. The copyright holder for this preprint

(which was not certified by peer review) is the author/funder, who has granted medRxiv a license to display the preprint in perpetuity.

It is made available under a CC-BY-NC 4.0 International license .

Coronary Events Registry (GRACE) ${ }^{[6]}$ Spencer et al. found that major bleeding occurred in $2.8 \%$ of 40, 087 patients with AMI enrolled in the GRACE. These patients were older, more severely ill, and more likely to undergo invasive procedures. ${ }^{[19]}$ The Can Rapid Risk Stratification of Unstable Angina Patients Suppress Adverse Outcomes With Early Implementation of the ACC/AHA Guidelines (CRUSADE) bleeding score was used to stratify the risk of major bleeding in NSTEMI patients; Subherwal et al. used 71,277 patients to derive and 17,857patients to validate a model that identifies 8 independent baseline predictors. ${ }^{[20]}$ Nikolsky et al. found age $>55$ years, female gender, estimated glomerular filtration rate $<60 \mathrm{~mL} / \mathrm{min} / 1.73 \mathrm{~m}^{2}$, pre-existing anaemia, administration of low-molecular-weight heparin within 48 hour pre-PCI, use of glycoprotein IIb/IIIa inhibitors, and intraaortic balloon pump use were independent predictors of bleeding. ${ }^{[17]}$

Our diagnostic model of in-hospital bleeding builds upon these studies in several ways. It is not a relative value but an absolute value. It includes only baseline factors, including age and Killip classification. It is easily calculated at patient presentation. It can retain discriminatory, thereby improving its effectiveness in clinical decision-making no matter what treatment is used (such as invasive care or antithrombotic drugs).It was developed in unselected real-world populations, including those who received initial invasive strategies and revascularization, and those who were conservatively treated without catheterization.Algorithms that can help doctors evaluate the diagnosis should be simple and easy to apply to the bedside, and should use clinical data routinely provided by the hospital.The nomogram we constructed for in-hospital bleeding captures most of the diagnostic information provided by the complete logistic regression model and is easier to use at the bedside.

\section{Study Limitations.}

This is a single center experience. Some patients were selected> 10 years ago, so their treatment may not meet current standards and techniques.It does not include bleeding related to catheterization. The use of antithrombotic drugs and previous bleeding history were not obtained in 
medRxiv preprint doi: https://doi.org/10.1101/2020.05.28.20115501; this version posted June 1, 2020. The copyright holder for this preprint

(which was not certified by peer review) is the author/funder, who has granted medRxiv a license to display the preprint in perpetuity.

It is made available under a CC-BY-NC 4.0 International license .

this study, so we cannot determine the effect of anticoagulation and previous bleeding history on bleeding risk.Finally, the c statistic of the study in-hospital bleeding model at 0.777 in the derivation and 0.7234 in the validation cohort is modest.

\section{Conclusions}

We developed and externally validated a moderate diagnostic model of in-hospital bleeding in patients with acute STEMI .

Abbreviations

$\mathrm{AMI}=$ acute myocardial infarction; $\mathrm{AF}=$ atrial fibrillation; $\mathrm{AIC}=$ Akanke information criterion ; $\mathrm{AUC}=$ area under the receiver operating characteristic curve ; $\mathrm{AVB}=$ atrioventricular block; $\mathrm{BIC}=$ Bayesian information criterion $\mathrm{CABG}=$ coronary artery bypass grafting; $\mathrm{CI}=$ confidence interval; $\mathrm{CKD}=$ chronic kidney disease; $\mathrm{CRUSADE}=$ Can Rapid Risk Stratification of Unstable Angina Patients Suppress Adverse Outcomes With Early Implementation of the ACC/AHA Guidelines; $\mathrm{HCD}=$ history of cerebrovascular disease ; GRACE $=$ global registry of acute coronary events registry; $\mathrm{MI}=$ myocardial infarction; NSTEMI =non ST elevation myocardial infarction; $\mathrm{PCI}=$ percutaneous coronary intervention; $\mathrm{ROC}=$ receiver operating characteristic $; \mathrm{STEMI}=\mathrm{ST}$ elevation myocardial infarction; TIMI =Thrombolysis in Myocardial Infarction;TRIPOD= Transparent Reporting of a multivariable prediction model for Individual Prognosis Or Diagnosis.

\section{Declarations}

\section{Ethical approval and consent to participate}

Ethic committee approved the study. Name of the ethic committee:Ethics committee of Beijing Anzhen Hospital Capital Medical University. Approved No. of ethic committee: 2019044X. It was a retrospective analysis and informed consent was waived by Ethics Committee of Beijing Anzhen Hospital Capital Medical University.

\section{Statement of human and animal rights}

All procedures performed in studies involving human participants were in accordance with the 
ethical standards of the institutional and/or national research committee and with the 1964 Helsinki declaration and its later amendments or comparable ethical standards. The study was not conducted with animals.

\section{Consent to publish}

Not applicable.

\section{Availability of data and materials}

All data generated or analysed during this study are included in this published article [and its supplementary information files].

Supplementary materials

The data are demographic, and clinical characteristics of hospitalized patients with acute STEMI.

$\mathrm{AGE}=$ age $; \mathrm{ALLAF}=$ atrial fibrillation; $\mathrm{AVB}=$ atrioventricular block; $\mathrm{BLOOD}=$ all-cause bleeding;

$\mathrm{CABG}=$ history of coronary artery bypass grafting $; \mathrm{CKD}=$ history of chronic kidney disease $; \mathrm{DM}=$

history of diabetes; $\mathrm{HBP}=$ history of hypertension; $\mathrm{HCD}=$ history of cerebrovascular disease;

HPCI=history of percutaneous coronary intervention; KI = Killip I ; KII = Killip II;KIII = Killip III ;

KIV = Killip IV; OMI=history of myocardial infarction; PCI=underwent PCI during hospitalization; $\mathrm{S}=\operatorname{sex}$

\section{Competing interests}

The authors declare that they have no competing interests.

\section{Funding}

This research received no external funding.

\section{Authors' contributions}

Yong Li contributed to generating the study data, analysed, interpreted the study data, drafted the 
medRxiv preprint doi: https://doi.org/10.1101/2020.05.28.20115501; this version posted June 1, 2020. The copyright holder for this preprint

(which was not certified by peer review) is the author/funder, who has granted medRxiv a license to display the preprint in perpetuity. It is made available under a CC-BY-NC 4.0 International license .

manuscript, and revised the manuscript. Yong Li is being responsible for the overall content as

guarantor. All authors read and approved the final manuscript.

\section{Acknowledgments}

Not applicable.

\section{References}

[1] Benjamin EJ, Muntner P, Alonso A, et al. Heart Disease and Stroke Statistics-2019 Update: A Report From the American Heart Association. Circulation. 2019. 139(10): e56-e528.

[2] Masoudi FA, Ponirakis A, de Lemos JA, et al. Executive Summary: Trends in U.S. Cardiovascular Care: 2016 Report From 4 ACC National Cardiovascular Data Registries. J Am Coll Cardiol. 2017. 69(11): 1424-1426.

[3] Albeiruti R, Chaudhary F, Alqahtani F, Kupec J, Balla S, Alkhouli M. Incidence, Predictors, and Outcomes of Gastrointestinal Bleeding in Patients Admitted With ST-Elevation Myocardial Infarction. Am J Cardiol. 2019. 124(3): 343-348.

[4] Mehran R, Rao SV, Bhatt DL, et al. Standardized bleeding definitions for cardiovascular clinical trials: a consensus report from the Bleeding Academic Research Consortium. Circulation. 2011. 123(23): 2736-47.

[5] Cornara S, Somaschini A, De Servi S, et al. Prognostic Impact of in-Hospital-Bleeding in Patients With ST-Elevation Myocardial Infarction Treated by Primary Percutaneous Coronary Intervention. Am J Cardiol. 2017. 120(10): 1734-1741.

[6] Moscucci M, Fox KA, Cannon CP, et al. Predictors of major bleeding in acute coronary syndromes: the Global Registry of Acute Coronary Events (GRACE). Eur Heart J. 2003. 24(20): 1815-23.

[7] Moons KG, Altman DG, Reitsma JB, et al. Transparent Reporting of a multivariable prediction model for Individual Prognosis or Diagnosis (TRIPOD): explanation and elaboration. Ann Intern Med. 2015. 162(1): W1-73.

[8] Thygesen K, Alpert JS, Jaffe AS, et al. Fourth universal definition of myocardial infarction (2018). Eur Heart J, 2019,40(3):237-269.

[9] Collins GS, Altman DG. Predicting the 10 year risk of cardiovascular disease in the United Kingdom: independent and external validation of an updated version of QRISK2. BMJ. 2012. 344: e4181.

[10] Sadjadieh G, Engstrøm T, Høfsten DE, et al. Bleeding Events After ST-segment Elevation Myocardial Infarction in Patients Randomized to an All-comer Clinical Trial Compared With Unselected Patients. Am J Cardiol. 2018. 122(8): 1287-1296.

[11] Matić DM, Ašanin MR, SDj S, et al. Incidence, predictors and prognostic implications of bleeding complicating primary percutaneous coronary intervention. Vojnosanit Pregl. 2015. 72(7): 589-95.

[12] Ko SQ, Valsdottir LR, Strom JB, et al. Meta-Analysis of Bleeding Risk Prediction Scores in Patients After Percutaneous Coronary Intervention on Dual Antiplatelet Therapy. Am J Cardiol. 2018. 122(11): 1843-1852.

[13] Jeger RV, Pfisterer M, Vogt DR, et al. Competing risks of major bleeding and thrombotic events with prasugrel-based dual antiplatelet therapy after stent implantation - An observational analysis from BASKET-PROVE II. PLoS One. 2019. 14(1): $\mathrm{e} 0210821$.

[14] Luo PJ, Lin XH, Lin CC, et al. Risk factors for upper gastrointestinal bleeding among aspirin users: An old issue with new findings from a population-based cohort study. J Formos Med Assoc. 2019. 118(5): 939-944.

[15] Lenti MV, Pasina L, Cococcia S, et al. Mortality rate and risk factors for gastrointestinal bleeding in elderly patients. Eur J Intern Med. 2019. 61: 54-61.

[16] Roe MT, Goodman SG, Ohman EM, et al. Elderly patients with acute coronary syndromes managed without revascularization: insights into the safety of long-term dual antiplatelet therapy with reduced-dose prasugrel versus standard-dose clopidogrel. Circulation. 2013. 128(8): 823-33.

[17] Nikolsky E, Mehran R, Dangas G, et al. Development and validation of a prognostic risk score for major bleeding in patients undergoing percutaneous coronary intervention via the femoral approach. Eur Heart J. 2007. 28(16): 1936-45.

[18] Ibanez B, James S, Agewall S, et al. 2017 ESC Guidelines for the management of acute myocardial infarction in patients presenting with ST-segment elevation: The Task Force for the management of acute myocardial infarction in patients presenting with ST-segment elevation of the European Society of Cardiology (ESC). Eur Heart J. 2018. 39(2): 119-177.

[19] Spencer FA, Moscucci M, Granger CB, et al. Does comorbidity account for the excess mortality in patients with major bleeding in acute myocardial infarction. Circulation. 2007. 116(24): 2793-801.

[20] Subherwal S, Bach RG, Chen AY, et al. Baseline risk of major bleeding in non-ST-segment-elevation myocardial infarction: the CRUSADE (Can Rapid risk stratification of Unstable angina patients Suppress ADverse outcomes with Early implementation of the ACC/AHA Guidelines) Bleeding Score. Circulation. 2009. 119(14): 1873-82. 